\title{
Elimination of Sendai (parainfluenza type 1) virus infection from mice by embryo transfer
}

\author{
P. Carthew, Maureen J. Wood and Carol Kirby \\ Medical Research Council, Experimental Embryology and Teratology Unit, Woodmansterne Road, \\ Carshalton, Surrey SM5 4EF, U.K.
}

\begin{abstract}
Summary. Preimplantation embryos collected from mice in the acute phase of Sendai virus infection were not infected. Transfer of embryos from infected donors did not transmit the virus to the recipient foster mothers or to their progeny. The pregnancies were normal with no differences in implantation rate or number of live births when compared with control transfers of embryos collected from non-infected donors.
\end{abstract}

\section{Introduction}

Embryo transfer is an established technique for the recovery of embryos stored in frozen embryo banks (Whittingham, 1979) and as a means of disease control (Singh et al., 1980) for the production of animals which are free from some micro-organisms.

As the technique is being used to supplement or to replace hysterectomy-rederivation of animals, it is pertinent to examine whether it is effective in the elimination of some economically important viral diseases. The mouse is particularly susceptible to Sendai (parainfluenza 1) virus infection resulting in severe enzootic or epizootic outbreaks of disease (Parker \& Reynolds, 1968). This infection has been studied extensively in the mouse (Robinson, Cureton \& Heath, 1968; Mims \& Murphy, 1973) and compared with other pneumonic viruses under germ-free conditions (Carthew \& Sparrow, 1980). The characteristic pathology of the infection is usually a severe bronchopneumonia which can be fatal. However, less attention has been paid to its effect on the outcome of pregnacy in the mouse or its ability to infect the pre- or post-implantation mouse embryo.

Tucker \& Stewart (1976) recorded intrauterine transmission of Sendai virus in two inbred strains of mouse which are susceptible to this infection. The intravenous route of infection was used and virus was isolated from $20 \%$ of the fetuses. Parker \& Reynolds (1968) isolated Sendai virus from murine plasma pools and suggested that a generalized infection or viraemia may occur during Sendai virus infection. Thus the infection could persist after hysterectomy-rederivation of infected animals. Fetal abnormalities have been noted after intranasal infection of mice (Ohba, 1959). However, Ohba (1959) did not claim that they were caused by direct virus infection of the embryo, but more probably by the indirect effect of the bronchopneumonia on the mother during pregnancy. Similarly, Coid \& Wardman (1971) found that infection of rats with Sendai virus on Days 4 or 5 of pregnancy resulted in resorption of embryos. Virus was isolated from only 1 of 9 gravid uteri examined.

The results of studies on Sendai virus infection of preimplantation embryos are contradictory. Tuffrey, Zisman \& Barnes (1972) demonstrated Sendai virus antigen by immunofluorescence in preimplantation mouse embryos from a spontaneous case of Sendai disease and also after in-vitro incubation of mouse embryos with Sendai virus. Attempts to repeat the in-vitro infection of 
preimplantation mouse embryos with Sendai virus, and to detect viral protein synthesis by immunofluorescence labelling were unsuccessful (Neighbour, 1977).

Because embryo transfer is likely to become increasingly important as a means of producing high quality mice, it has become necessary to clarify whether preimplantation embryos from mothers acutely infected with Sendai virus can carry or transmit the virus.

\section{Materials and Methods}

Source and collection of embryos

Immature MF1 mice were induced to superovulate by intraperitoneal injections of 5 i.u. PMSG (Folligon: Intervet, Cambridge, U.K.) followed $48 \mathrm{~h}$ later by 5 i.u hCG (Chorulon: Intervet). After the hCG injection the mice were paired with MF1 males and examined next morning for copulation plugs (Day 1 of pregnancy).

On Day 4 of pregnancy the females were killed by cervical fracture and the uterine horns were removed. Morulae and early blastocysts were flushed from the uteri in a modified Krebs-Ringer solution with Hepes buffer (M2; Quinn, Barros \& Whittingham, 1982) and pooled in Medium M2. Morphologically normal morulae and early blastocysts were separated from embryos which appeared retarded or degenerate. The embryos were washed through at least 3 changes of Medium M2 (2 ml per wash) to remove all traces of blood and tissue fluid before transfer into foster mothers.

\section{Embryo transfer}

Morulae and early blastocysts were transferred surgically to both uterine horns ( 5 embryos per horn) of Day-3-pseudopregnant C57BL/6JLac $\times$ CBA/CaLac F1 hybrid (B6CBF1) foster mothers. Pseudopregnancy was induced in these females by mating with a sterile male.

The embryo transfers were performed in a positive-pressure laminar-flow cabinet with a specially constructed end-port facility. The end-port was placed centrally in the Perspex right-hand end panel of the cabinet and constructed so that an isolator could be linked directly to the end panel. The port was opened and closed by a locking mechanism from inside the cabinet. Recipient mice were removed through the port of a negative-pressure isolator directly into the laminar-flow cabinet and similarly returned to the isolator after surgery. The person performing the embryo transfer had no contact with the infected donor mice or their tissues. Control embryos were transferred before those from Sendai virus-infected donors.

The recipients of control and experimental embryos were kept in separate negative-pressure isolators where they littered and reared their offspring.

Virus

Sendai virus (parainfluenza 1) obtained from the Public Health Laboratories, Colindale, London, U.K., was propagated as described by Coid \& Wardman (1971) in the allantoic cavity of 10-day-old embryonated hens' eggs (Wickham Laboratory, Wickham, Hampshire, U.K.).

\section{Administration of virus}

The Sendai virus suspension (0.025 ml) containing $5 \times 10^{5} \mathrm{EID}_{50}$ (egg infectious doses, 50\% end point) per $\mathrm{ml}$ was inoculated intranasally into female MFl mice before induction of superovulation. The donors were infected 7 days before embryo collection, i.e. 1 day before the PMSG injection. Control mice were dosed with uninfected egg allantoic fluid. Experimental and control groups were housed in separate negative-pressure isolators. 
Attempts to isolate Sendai virus from preimplantation mouse embryos

Two attempts were made to isolate virus from preimplantation embryos taken from Sendai virus-infected mothers. The first batch of embryos was sorted so that only morphologically normal morulae and blastocysts were used for embryo transfer (60 embryos) and virus isolation (19 embryos). The second batch was scored so that the embryos were distinguished as normal or retarded/degenerating embryos. Approximately 100 embryos from each group were tested for the presence of virus.

Morphologically normal embryos and retarded/degenerating embryos collected from infected and control donors were suspended in $1 \mathrm{ml}$ phosphate-buffered saline then frozen and thawed three times. Half of each sample was injected into the allantoic cavity of 10-day-old embryonated hens' eggs and the resultant allantoic fluids were tested as described by Coid \& Wardman (1971). The remaining $0.5 \mathrm{ml}$ of each sample was inoculated intranasally into MF1 mice as a mouse antibody production test (Parker \& Reynolds, 1968). After 28 days the mice were bled by cardiac puncture and tested for antibody to Sendai virus by haemagglutination inhibition, complement fixation and ELISA testing (Parker \& Reynolds, 1968; Parker, O’Beirne \& Collins, 1979; Carthew, Gannon \& Whisson, 1981).

\section{Histological examination of animal tissues}

After removal of the uterine horns from the donor mice the lungs were taken and fixed in formalin or cold $95 \%$ ethanol. Lung tissue was examined histopathologically for Sendai virus lesions and by immunohistochemical staining for specific Sendai virus replication (Carthew \& Sparrow, 1980). The B6CBF1 foster mothers and their litters were bled out at 3 weeks post partum (to allow any possible antibody titre to develop) and the lungs removed. The sera were tested for the presence of Sendai antibody and the lungs were examined for Sendai virus as described above.

\section{Results}

The experimental scheme adopted to test whether Sendai virus is transmissible during embryo transfer from infected mothers is shown in Text-fig. 1.

Experimental infection with Sendai virus had no significant effect on the production of normal embryos or on the outcome of embryo transfer (Table 1).

All the mice dosed intranasally with Sendai virus were acutely infected. Lesions characteristic

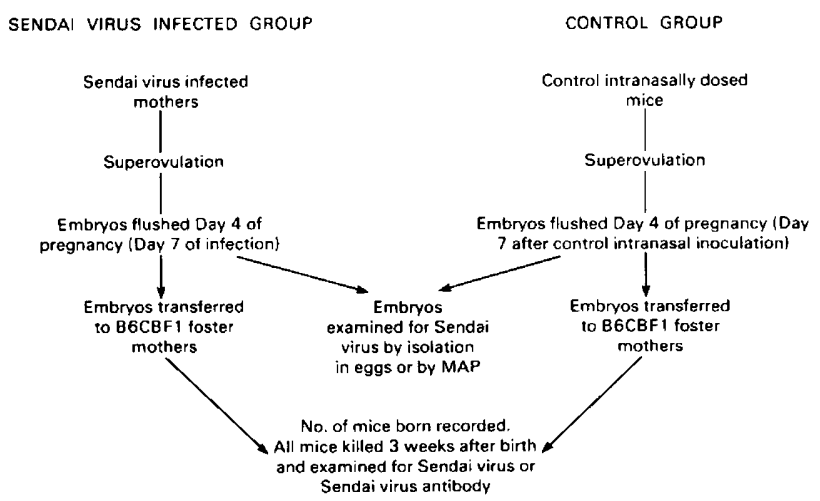

Text-fig. 1. Experimental scheme to examine whether Sendai virus is transmitted during embryo transfer in mice. MAP = mouse antibody production test. 
Table 1. Effect of acute Sendai virus infection in the donor on the number of morulae and blastocysts collected and on subsequent viability of the embryos after transfer to Sendai virus-free recipients

\begin{tabular}{|c|c|c|c|c|c|c|c|}
\hline & \multicolumn{2}{|c|}{ No. of females } & \multirow{2}{*}{$\begin{array}{c}\text { No. of } \\
\text { morphologically } \\
\text { normal } \\
\text { embryos* }\end{array}$} & \multirow{2}{*}{$\begin{array}{l}\text { Mean no. } \\
\text { of embryos } \\
\text { per mated } \\
\text { female }\end{array}$} & \multirow{2}{*}{$\begin{array}{c}\text { No. of } \\
\text { embryos } \\
\text { transferred }\end{array}$} & \multirow{2}{*}{$\begin{array}{l}\text { No. of } \\
\text { recipients }\end{array}$} & \multirow{2}{*}{$\begin{array}{l}\text { No. of } \\
\text { live births } \\
(\%) \dagger\end{array}$} \\
\hline & Paired & Mated & & & & & \\
\hline Control & 20 & 14 & 79 & $5 \cdot 6$ & 60 & 6 & $36(60)$ \\
\hline Virus-infected & 20 & 16 & 93 & $5 \cdot 8$ & 70 & 7 & $39(56)$ \\
\hline
\end{tabular}

* Day 4 of pregnancy.

$\dagger \%$ of embryos transferred giving rise to live young.

of Sendai virus (Carthew \& Sparrow, 1980) were found in the lung sections of infected donors but extensive attempts to isolate virus from the flushed embryos by egg inoculation and by transmission testing in Sendai virus-free mice were unsuccessful. None of the isolation techniques revealed any Sendai virus in the morphologically normal or the retarded and degenerating embryos. No lesions were found in the lung tissue from the control donors. Furthermore, no lesions characteristic of the acute or recovery phase of infection were seen in the foster mothers or their progeny. Serological tests for virus antibody were all negative.

\section{Discussion}

One problem that is evident from the work of Tuffrey et al. (1972) is the difficulty in interpretation of tests such as the indirect immunofluorescence test applied to preimplantation embryos to demonstrate viral antigens. Without a known positive control it is difficult to see how this test can be applied unless virus is also demonstrated by classical isolation techniques using tissue culture to confirm the result. We have used both a tissue culture system and an animal transmission system (the mouse antibody production test) to detect Sendai virus associated with preimplantation embryos from acutely infected donors. Our failure to detect any Sendai virus confirms the work of Neighbour (1977). The possibility of virus being absorbed to the embryos, as suggested by Tuffrey et al. (1972), can be excluded because our experimental design was such that this would have been detected.

The demonstration that Sendai virus is not transmitted from acutely infected pregnant mice to the developing preimplantation embryo or the recipient foster mother is an important consideration in terms of the application of embryo transfer as a technique for cleaning up infected colonies of mice. Numerous studies have shown that Sendai virus infection is widespread not only in the United Kingdom (Gannon \& Carthew, 1980) but also throughout the world (Parker \& Reynolds, 1968; Itoh et al., 1978).

The possibility of other common indigenous murine virus diseases being transmitted or eliminated during embryo transfer is unresolved. We are investigating other acute phase murine virus diseases which are hepatotropic, as virus can be shed after replication into the peritoneal cavity and could thus contaminate the surface of the uterine horns. This could lead to the transfer of virus along with (but not actually infecting) the perimplantation embryos.

We thank Mr Terry Pendry for assistance with the design and construction of the isolator/laminar flow cabinet system used in this work; the M.R.C. workshops at Carshalton for the construction of the special end-port facility in the laminar flow cabinet; Roger Gilford for assistance with the serological testing; David Tucker for monitoring the isolators used; and Miss Joyce Breaden for assistance with the histology. 


\section{References}

Carthew, P. \& Sparrow, S. (1980) A comparison in germfree mice of the pathogenesis of sendai virus and pneumonia virus infections. J. Path. 130, 153-158.

Carthew, P., Gannon, J. \& Whisson, I. (1981) A comparison of alkaline phosphatase and horseradish peroxidase conjugated antisera in the ELISA test for antibodies to Reovirus 3, mouse hepatitis and Sendai virus. Lab. Anim. 15, 69-73.

Coid, C.R. \& Wardman, G. (1971) The effect of parainfluenza type 1 (Sendai) virus infection on early pregnancy in the rat. J. Reprod. Fert. 24, 39-43.

Gannon, J. \& Carthew, P. (1980) Prevalence of indigenous viruses in laboratory animal colonies in the United Kingdom 1978-1979. Lab. Anim. 14, 309-311.

Itoh, T., Kagiyama, N., Hiroshi, I., Okada, O., Takashima, S. \& Gito, H. (1978) Sendai virus infection in a small mouse breeding colony. Jap. J. vet. Sci.40,615. 618.

Mims, C.A. \& Murphy, F.A. (1973) Para-influenza virus sendai infection in macrophages, ependyma, choroid plexes, vascular endothelium and respiratory tract of mice. Am. J. Path. 70, 315-328.

Neighbour, P.A. (1977) Susceptibility of the mouse preimplantation embryo to viral pathogenesis. Ph.D. thesis, University of London.

Ohba, N. (1959) Formation of embryonic abnormalities of the mouse by a viral infection of mother animals (second report). Acta path. jap. 9, 149-157.

Parker, J.C. \& Reynolds, R.K. (1968) Natural history of
Sendai infection in mice, Am. J. Epidemiology $\mathbf{8 8}$, 112-125.

Parker, J.C., O'Beirne, A.J. \& Collins, M.J. (1979) Sensitivity of enzyme linked immunosorbent assay, complement fixation and haemagglutination inhibition serological tests for detection of Sendai virus antibody in laboratory mice. J. Clin. Microbiol. 9, $444-449$.

Quinn, P., Barros, C. \& Whittingham, D.G. (1982) Preservation of hamster oocytes to assay the fertilizing capacity of human spermatozoa. J. Reprod. Fert. 66, 161-168.

Robinson, W.E., Cureton, R.J.R. \& Heath, R.B. (1968) The pathogenesis of Sendai virus infection in the mouse lung. J. med. Microbiol. 1, 89-95.

Singh, E.L., Thomas, F.C., Hare, W.C.D., Mitchell, D., Eaglesome, M.D., Randall, G.C.B., Betteridge, K.J., Dulac, G.C., Samagh, B.S. \& Papp-Vid, G. (1980) Embryo transfer in disease control. Theriogenology 17, 108 .

Tucker, M.J. \& Stewart, R.B. (1976) Intrauterine transmission of Sendai virus in inbred mouse strains. Infection and Immunity 14, 1191-1195.

Tuffrey, M., Zisman, B. \& Barnes, R.D. (1972) Sendai (para-influenza 1) infection of mouse eggs. Br. J. exp. Path. 53, 638-640.

Whittingham, D.G. (1979) In vitro fertilization, embryo transfer and storage. Br. med. Bull. 24, 105-111.

Received 14 February 1983 